\title{
Judicial Cosmopolitanism
}

The Use of Foreign Law in Contemporary

Constitutional Systems

Edited by

Giuseppe Franco Ferrari

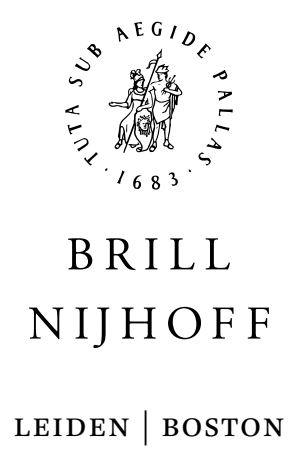

For use by the Author only | (C) 2020 Koninklijke Brill NV 


\section{Contents}

Notes on Contributors IX

Introduction: Judicial Constitutional Comparison and Its Varieties $\quad 1$ Giuseppe Franco Ferrari

\section{PART 1}

Common Law Countries

Splendid Isolation or Open to the World? The Use of Foreign Law by the UK Supreme Court $\quad 29$

Justin O. Frosini

The Use of Foreign Law in Irish Constitutional Adjudication

69

Oran Doyle and Tom Hickey

Legal Comparison Within the Case Law of the Supreme Court of the United States of America 94

Giuseppe Franco Ferrari

Comparative Law in the Jurisprudence of the Supreme Court of

Canada $\quad 140$

Nino Olivetti Rason and Sara Pennicino

Developing an Indian Constitutional Jurisprudence Drawing on Judicial Thinking in the Rest of the Common Law World $\quad 177$ Anton Cooray

The Practice of Comparative Law by the Supreme Courts of Australia and New Zealand 194

Maurilio Gobbo

The Comparative Legal Tool-Kit of the Constitutional Court of South Africa 217

Angelo Rinella and Valentina Cardinale 


\section{PART 2}

\section{Continental Europe}

Comparative Law and the French Constitutional Council $\quad 263$

Paolo Passaglia

Comparative Reasoning in Constitutional Litigation: Functions,

Methods and Selected Case Law of the German Federal

Constitutional Court $\quad 295$

Sonja Haberl

Comparative Law in the Case Law of the Austrian Constitutional

Court $\quad 325$

Christoph Grabenwarter

Conspicuous Absentees in the Dutch Legal Order: Constitutional Review \& A Constitutional Court 337

Wim Voermans

The Constitutional Court of Belgium and the Use of the Comparative Argument. From the Dialogue with the "Sister Courts" to the Dialogue with the European Courts $\quad 348$

Paolo Carrozza

The Spanish Constitutional Court and Foreign and Comparative Law: Theory and Practice of a Marriage of Convenience $\quad 375$ Ángel Aday Jiménez Alemán

The Use of Comparison in the Swiss Federal Tribunal Case Law 402 Sergio Gerotto

Is There a Middle Ground between Constitutional Patriotism and Constitutional Cosmopolitanism? The Portuguese Constitutional Court and the Use of Foreign (Case) Law 424

Catarina Santos Botelho

The Italian Constitutional Court

Vincenzo Zeno-Zencovich 


\section{PART 3 \\ Northern Europe}

The Use of Foreign Precedents in Constitutional Interpretation by the Nordic Courts $\quad 461$

Francesco Duranti

Foreign Materials in the Judgments of the Constitutional Court of the Republic of Latvia $\quad 476$

Anita Rodina

The Use of Foreign Law by Estonian Supreme Court $\quad 501$

Madis Ernits

\section{Eastern Europe}

The Russian Constitutional Court and the Judicial Use of Comparative Law: A Problematic Relationship $\quad 531$

Mauro Mazza

Comparative Analysis in the Case Law of the Constitutional Tribunal of

Poland $\quad 567$

Miroslaw Granat

The Use of Foreign Legal Materials by the Constitutional Court of the Czech Republic $\quad 589$

Jana Ondřejková, Kristina Blažková and Jan Chmel

Use of Foreign Law in the Practice of the Hungarian Constitutional Court With Special Regard to the Period between 2012 and $2016 \quad 618$

Csaba Erdös and Fanni Tanàcs-Mandàk

Constitutional Adjudication and Comparative Law in the Republic

of Croatia 650

Carna Pistan

The Use of Foreign and Comparative Law by the Constitutional Court and the High Court of Cassation of Romania $\quad 686$

Camelia Toader 
The Use of Comparative and International Law by the Constitutional Court of Bosnia and Herzegovina 708

Laura Montanari

National Courts and Comparative Law - The States of Former Yugoslavia (Slovenia, Croatia, Serbia, Bosnia-Herzegovina, Macedonia and Montenegro) 745

Gian Antonio Benacchio

\section{PART 5}

Asia

The Recourse to Foreign Legal Sources by the Southeast Asian Constitutional and Supreme Courts $\quad 771$

Serena Baldin

Use of Foreign and Comparative Law by the Supreme Court of Japan 800

Akiko Ejima

\section{PART 6}

\section{Latin America}

Foreign Law and Foreign Case Law before Latin American

Constitutional and Supreme Courts $\quad 827$

Francesca Polacchini

\section{RT 7 \\ Israel}

The Supreme Court of Israel and the Use of Comparative Law 853 Leonardo Pierdominici

Index of Authors $\quad 871$

Index of Cases $\quad 883$ 


\title{
Conspicuous Absentees in the Dutch Legal Order: Constitutional Review \& A Constitutional Court
}

\author{
Wim Voermans
}

\section{1 \\ The Strange Setup of Constitutional Review in the Netherlands}

The Netherlands may prove to be a bit of a killjoy in this book since the Dutch legal system does not have a Constitutional Court, nor much in the way of constitutional review proper. The Dutch Constitution even contains a ban on constitutional review. With these features, the Netherlands is the odd one out in the family of modern Western constitutional systems. Most modern constitutional systems have, as a sort of a logical sequel to present-day requirements of the rule of law, both a constitutional court and judicial constitutional review. In what other way is it possible to safeguard and implement the constitution, one might wonder, if there is no review by an independent arbiter? This contribution will not take a position on this but will try to explain why the Dutch system is so different and playing out of tune with the rest of the European family. Secondly, it illustrates how the Dutch manage to keep rule of law safeguards in check even without full-fledged constitutional review.

\subsection{The Absence of a Constitutional Court}

There is no special Constitutional court in the Netherlands, which deals with constitutional questions as there is in most other European countries. What is even more peculiar is that in the (more than $\left.{ }^{1}\right)$ 200-year history of the Dutch constitution it was never seriously considered. ${ }^{2}$ The main reason for this relates to the ban on constitutional review enshrined in article 120 of the Constitution, which reads:

1 The Dutch Constitution dates back to 1814, making it the second oldest Constitution in the World. See W. Voermans, 'Constitutional Law' (Chapter 15), in: Chorus, J., Hondius, E., Voermans, W. (eds.), Introduction to Dutch Law (5th edition). Alphen aan den Rijn: Wolters Kluwer 2016, 320-321.

2 A recent report of the 'De nationale conventie' (National Convention) in 2006 floated the idea of a Constitutional Court in the Netherlands. The idea was not picked up. Nationale Conventie, Hart voor de publieke zaak; Aanbevelingen van de Nationale conventie voor de $21 \mathrm{e}$ eeuw. The Hague 2006, $47 \mathrm{ff}$. 
The constitutionality of Acts of Parliament and treaties shall not be reviewed by the Courts. ${ }^{3}$

The ban on constitutional review expresses two things. First of all the notion of dispersed constitutional review. All Dutch courts can engage in constitutional review, except for the review Acts of Parliament and Treaties. Secondly, article 120 of the Dutch Constitution marks the constitutional position of the courts: they cannot trump the final outcome of Parliamentary debate or the expressed will of the international community (in a Treaty) - the courts are in the Dutch system - more or less subordinate to the will of the people expressed by the sovereignty of the national Parliament. But only to this national body. The courts do not owe this reverence to lower ranking parliaments like municipal or provincial councils. The will of the people is represented in these lower ranking, elected councils as well, and these councils do engage in legislation too. Provincial and municipal legislation is subject to constitutional review by the courts (all the courts). A strange inconsistency at first glance.

Why did the Dutch chose for this system and not opt for a single constitutional court, which might be more efficient, allowing to pool constitutional knowledge into one organization? It would have certainly aligned the Dutch system better with the constitutional systems of their European neighbours.

\subsection{Land of Minorities and Political Compromise: Polderculture}

One of the main reasons for this particular Dutch position has to do with the fact that the Netherlands are historically a land of minorities. For centuries. Rights and privileges of - amongst others - (religious) minorities were the reason for the 16th century uprising against the Habsburgs (resulting in the birth of the Netherlands). In the four centuries of its existence, the Netherlands have always been rife with separatist groups, all kinds of forms of separatism, minority-struggles and so on. Peaceful fragmentation is a typical trait of Dutch social-cultural and political life, up until the present day. This is for instance reflected in the politics of the country. Political parties are manifold and most of them (very) small. This means that they will always - as a fact of political life - have to compromise and work together to form a majority coalition. The Dutch House of Representatives (Tweede Kamer) currently after the 2017 elections - consists of 13 different political groups in a House

3 A somewhat liberal English translation of the original Dutch text of article 120 of the Dutch Constitution taken from Constitute https://www.constituteproject.org/constitution/Netherlands_2008.pdf?lang=en. The original Dutch text of article 120 reads: 'De rechter treedt niet in de beoordeling van de grondwettigheid van wetten en verdragen.' 
of 150 seats. Only one group packs about $20 \%$ of the seats, the three runner up groups pack about $12-13 \%$, nine groups fall below the $10 \%$ threshold, six of which would fall under the $5 \%$ electoral threshold Germany has put into place. To say the political landscape is fragmented would be a euphemism: it is splintered. In the Dutch Senate or Upper House (Eerste Kamer), the picture is more or less the same: at the end of 2015, twelve groups were represented in a House of 75 seats. This political fragmentation is a recurrent feature of the Dutch minority nation. The political landscape is and has been fragmented ever since the first general elections of 1922 . One would believe that in a country like this politics and policymaking would be permanently paralyzed, but in fact, they are not. The Dutch have learned to manage their political fragmentation by typical ways of compromise politics, involving both political parties and social-economic 'partners' (unions, employers organisations and interest groups). The so-called 'polder model'-compromises or (as an indication of the political culture) 'polder culture.4 In a coalition country like this, relying on so many actors and compromises, it stands to (some) reason that it is not up to judges to review and quash the result of hard wrought compromises and tradeoffs enshrined in legislation.

The ban on constitutional review, expressed in the Constitution ever since 1848, denotes the supremacy of an Act of Parliament vis-à-vis the Constitution, which is further enhanced by Article 140, a transitory provision, reading: 'Existing Acts of Parliament and other regulations and decrees which are in conflict with an amendment to the Constitution shall remain in force until provisions are made in accordance with the Constitution.'

\section{$2 \quad$ How Do the Dutch Operate Constitutional Review?}

The ban on constitutional review of Acts of Parliament and the absence of a constitutional court does not mean that constitutional review does not exist in the Netherlands. It does. In this paragraph, we will look into the ways the Dutch have organized it.

\subsection{Who Guards the Constitution if There is no Constitutional Court?}

Barring the courts from constitutional review of Acts of Parliament and Treaties seems rather drastic and giving (too) much rein to political actors maybe: a somewhat naïve belief, perhaps, in the sovereignty of Parliament and its

4 See R.B. Andeweg and A.I. Galen, Governance and Politics of the Netherlands, Basingstoke, Palgrave Macmillan, 2014. 
power to act responsibly as guardian of the Constitution. Because that is where the responsibility for constitutional review lies in the Netherlands: with Parliament. It is up to the Houses of Parliament to review the constitutionality of bills. Parliamentarians are, for this task, not totally left to their own devices. A special advisory division of the Council of State offers assistance. Prior to the tabling of any bill before Parliament, the Council of State reviews bills (as well as proposals for government decrees) and, on that occasion, tries to have a keen eye for constitutional issues. Likewise ratification bills for any Treaty are submitted for consultation to the Council of State. Consultation of the Council of State is mandatory under the Dutch Constitution (art. 73). After the Council of State has vetted a bill they write a report which expresses their findings. The report, that even has a sort of a 'verdict' at the end, is annexed to the bill and sent to Parliament. It there acts as a preliminary report on the bill with the expert (constitutional) opinion of the authoritative Council of State. And even though not all of the reports of the Council of State are followed up upon automatically, the opinions of the Council of State carry a lot of weight.

A Dutch bill has to pass both Houses of Parliament before it can become a true Act of Parliament. The House of Representatives is the politically most important one of both Houses. Constitutional issues do not always play a prominent role in the debates of this chamber and one might be right in fearing that constitutional safeguards and the constitution itself maybe compromised under the pressure of pure political considerations. Due to the typical setup of the Dutch legislative procedure there is however a safety net. The Dutch legislative procedure is sequential (not iterative like in a lot of countries) meaning that a bill passes the House of Representatives first and afterwards is debated in the Upper House or Senate. This gives the Senate the power of a veto player. They have to be very carefully in using this veto power, because they have a weaker democratic mandate than the House of Representatives. The Dutch senate is chosen, indirectly by the Councillors of the Dutch Provinces. The House of Representative is chosen directly by the people every four years. Trying to head on - substitute their decision on a bill contrary to the will of the House of Representatives on mere political grounds, compromises the Senate. It triggers questions on their mandate, weak democratic pedigree and - on the whole their position. The Senate therefore is reluctant to give a full-fledged second political appraisal of a bill when they debate it. The Dutch Senate always tries to assess a bill on more technical grounds than the House of Representatives does and by this placing itself in a more complementary or indeed subsidiary role. One of the 'technical' aspects the Senate looks into is the constitutionality 
of a bill. On the rare occasions that the Dutch Senate rejects (and effectively vetoes) a bill ${ }^{5}$ constitutional arguments or issues mostly feature among the main reasons for rejection (together with 'legal' problems, problems under international law or problems with implementability or feasibility). So in fact there are constitutional safeguards against Acts in Parliament, even though they are not available for an individual as such. The Houses of Parliament act as guardians of the Constitution when scrutinizing bills and ratification acts. Of course, their appraisal will be predominantly political, even though they have a preliminary constitutional report of the Council of State at their disposal.

\subsection{Constitutional Review by Other Courts}

It would be a misunderstanding to say that the Dutch system lacks constitutional review. There is. All courts perform constitutional review, with the exception of constitutional review of Acts of Parliament and Treaties. Government decrees, Ministerial regulations, policy rules, municipal and provincial byelaws, administrative decisions, etc. all of these measures can be reviewed against the constitution. Acts of Parliament and Treaties do only make up about $3 \%$ of the combined total of Dutch and European legislation. This puts the ban on constitutional review somewhat in context albeit that this $3 \%$ does represent the most important part of the legislative stock.

If a citizen wants to lodge a case against a rule or administrative decision on the basis that it runs counter to the Dutch Constitution he or she is free to do so, whether is a fiscal, civil, criminal or an administrative case. The court handling the case will look into it and rule on it - in theory. Over the last decades the courts have begun to show - too much to my mind - reverence for the Dutch legislature even beyond the national Parliament. The ban on constitutional review - from article 120 Constitution - casts a shadow that goes beyond the exact wording of the article itself. ${ }^{6}$

The Dutch Supreme Court (and the highest Administrative Courts) have begun to develop a 'political question'-doctrine based on article 120 of the Dutch Constitution over the last decades. Article 120 Constitution is interpreted very strictly and restrictively. The Supreme Court for instance extended the ban of Article 120 and ruled in 1989 that the courts are even precluded from reviewing Acts of Parliament for compatibility with (unwritten) fundamental general

5 About a hundred bills a year are handled by Dutch Parliament on average. Between 2 and 3 percent of these are rejected by the Senate.

6 See Wim Voermans, De bestuursrechter en artikel 120 Grondwet, JB plus 2003, 152-151. 
principles of law or compatibility with the Charter of the Kingdom. ${ }^{7}$ This and other case law suggests that general fundamental principles of law may prevail over Acts of Parliament. It is, however, not always for the courts to establish this. Courts in recent years have been ever less inclined to fully review rules and legislation stemming from democratically elected councils, and courts are very reluctant to ordain democratically underpinned (lower ranking) legislators to act, even where these councils or Parliament are legally obliged to (e.g. under EU Law). ${ }^{8}$

A second cast-shadow of article 120 Constitution has found its way in the General Administrative Law Act (GALA) of 1992 - an important framework act on administrative law and administrative law procedures. On the basis of article 8:3 GALA direct administrative appeal against a generally binding regulation, $e \mathrm{~g}$, statutory instruments or byelaws, is made impossible. An administrative appeal against generally binding regulations (most of the time a product of a democratically underpinned legislature) can only lodged indirectly, by opposing an implementing decision based on such a regulation or by attacking it as part of a tort action. Direct remedies to appeal and invalidate legislative products are - at present - very difficult to come by in the Dutch system.

International Law and EU-Law: The Luxembourg and Strasbourg Court as Stand-Ins

How do the Dutch cope with such a restrictive review and appeal system? Doesn't this system meet with a lot of resistance? In all fairness: hardly. There have been lukewarm attempts to alleviate the ban of article 120 Constitution but they haven't really caught on and passed the thresholds for effective constitutional revision. ${ }^{9}$

7 HR 14 April 1989, NJ 1989469.

8 See for instance Supreme Court 21 March 2003, AB 2004, 39 and SEW (52), 2004, 232-238 annotated by Leonard Besselink (Waterpakt).

9 In 2002 a bill (28 331) was introduced by the Dutch M.P. Halsema to provide for a weak form of constitutional review. The proposed revision of article 120 of the Dutch Constitution would empower the judiciary to review Acts of Parliament for compatibility with some of the constitutional provisions concerning fundamental rights. At the time, the proposal met with the Cabinet's consent (2001-2002, 28 355). The bill is however a very slow train coming: it is still pending, awaiting a second reading and a two-thirds majority in Parliament, to achieve the constitutional amendment threshold, after having passed both Houses of Parliament in first reading almost a decade ago. The $2 / 3$ majority sought for in second reading - the supermajority needed to effect a constitutional revision - is however not in sight yet. 
The heart of the matter is that the Dutch do have recourse to full-fledged constitutional review, but not under their own constitution or before their own domestic court. Their review needs are catered for by the EU treaty and International Treaties (especially fundamental rights treaties like the important $\mathrm{Eu}-$ ropean Convention on Human Rights) and the stand-in Constitutional Courts of the European Court of Justice in Luxembourg and the Strasbourg Court on Human Rights. The articles 93 and 94 of the Dutch Constitution provide for direct and domestic effect of self-executing rights and obligations emanating from provisions in international treaties or decisions.

So review of Dutch Parliamentary Acts, generally binding regulations and even Treaties on their conformity with international Treaties and EU law is made possible by a U-turn construction. Article 93 of the Constitution provides that provisions of Treaties and resolutions of international organizations which 'maybe binding on all persons by virtue of their contents' (i.e. be self-executing), 'shall be become binding after they have been published.' This means that self-executive international provisions have direct domestic effect. On top of this Article 94 of the Constitution provides that Dutch parliamentary Acts do not apply if they are at variance with self-executing treaty provisions. Therefore, self-executive provisions of treaties and international resolutions have priority over domestic Dutch law. Even priority over Dutch constitutional provisions.

Two important treaties containing such self-executive provisions are the ECHR and the (UN) International Covenant on Civil and Political Rights. During the last decades, these two Conventions have come to serve as a bill of rights which allows Dutch courts to annul Acts of Parliament that run counter to provisions laid down in these conventions. Once the courts discovered this new tool, they made increasing use thereof, especially in matters of family law, social security law and criminal procedure. ${ }^{10}$ In the second place, the application of EU law can lead to review of Acts of Parliament and of other laws by the courts as well.11

The supremacy of international law is a clear indication that the Netherlands adheres to the monistic doctrine. ${ }^{12}$ There is, however, a major exception with regard to unwritten or customary international law. Whatever its binding

10 P. van Dijk, Domestic Status of Human Rights Treaties and the Attitude of the Judiciary: The Dutch Case, in: Fortschritt im Bewusstsein der Grund- und Menschenrechte. Festschrift für Felix Ermacora, Kehl am Rhein etc 1988, 631-650, and see Chapter 15 no 22.

11 S. Prechal, Directives in EC Law, Oxford 2005.

12 Parts of this paragraph are taken from Wim Voermans, 'Constitutional Law', in: Jeroen Chorus, Ewoud Hondius and Wim Voermans (eds.), Introduction to Dutch Law, 5th edition. Wolters Kluwer; Deventer 2016, 317-367. 
force and ranking for the legislature and the administration, the courts are precluded from applying such law - even if it is self-executing - with priority over statutory domestic law. There is some dispute about the consistency of this exception with the rest of the direct-effect-doctrine.

As for treaties and resolutions of international organizations, their priority over domestic law is not in dispute. In order to be applied they should be obligatory, self-executing and duly published. The most important examples are the $195^{\circ}$ European Convention on Human Rights and the 1966 International Covenant on Civil and Political Rights (ICCPR). In contrast, the Universal Declaration on Human Rights of 1948 is not considered to be binding, since the UN General Assembly has not been empowered to take binding decisions.

\subsection{Priority of International Written Law Acting as a Constitutional Review-Surrogate}

The priority of 'written' international law is spelled out in Article 94 Constitution. ${ }^{13}$ Statutory regulations in force within the Kingdom shall not be applicable if such application conflicts with self-executing international legal provisions. Thus Acts of Parliament, the Constitution itself and even the Kingdom's Charter must be in conformity with international law. Both prior and subsequent legislation has to be reviewed.

Most international instruments are silent as to the question of self-execution; therefore, it falls to the domestic courts to decide. The criteria to determine whether an international law provision is self-executing are its nature, contents, wording and the parties' intention. The courts sometimes additionally examine whether in the case at hand the application of the international provision would lie 'outside the law-making task of the judiciary'. ${ }^{14}$

It is hard for courts to decide on the self-executive nature of provisions of international treaties, first because of the opaqueness of the provisions and lack of certainty as regards the intent of the treatymakers, and secondly because of the potential dramatic effects for the effect for domestic law. There has, for instance, been some debate and uncertainty with respect to the resolutions of the UN Security Council containing (economic) sanctions. Do they have a selfexecutive character and therefor trump all national law? The Dutch legislature needed to step in to resolve the issue. Nowadays the implementation of UN sanctions is secured by general Acts like the Sanctiewet 1977 (Sanctions Act), Stb 1980 93. Acts like these create the necessary legal obligations and enable

\footnotetext{
13 See L. Erades, International Law and the Netherlands Legal Order, in: H.F. van Panhuys et al III, 1980, 375-434.

14 See, inter alia, HR 12 October 1984, NJ 1985230 and HR 30 January 1996, NJ 1996288.
} 
the administration to interfere through a system of licensing (and ban for what is not licensed).

\subsection{Priority of EU Law}

In Dutch legal doctrine, there has also has been discussion about the title under which the law of the EU takes (direct domestic) effect within the Dutch legal order. Some relied on Articles 93 and 94 Constitution; others on the preeminence and superiority of the EU legal order as spelled out in the case law of the European Court of Justice, considering Articles 93 and 94 as merely declaratory as far as EU law is concerned. The dispute has lost its relevance; the EU law's superiority is firmly and generally accepted - ever since the Costa E.N.E.L. ruling of the Court of Justice ${ }^{15}$ and now under the EU Treaty itself. ${ }^{16}$

Nowadays EU law poses other problems. As is the case with several other Member States, the Netherlands is increasingly at fault in implementing EU directives in time. Criticism of the EU Commission and some judgments of the European Court of Justice condemning the Netherlands have led to some soul-searching in Parliament. During the debate, the following causes were discerned: participation of the Dutch administration in the preparatory phases of EU legislation lacks coordination; the administration is too slow in initiating the requisite domestic legislation, particularly when the subject-matter of a directive touches upon the spheres of more than one ministry; the legislative process itself is too time-consuming because of the volume of official and non-official advice that is being sought; and, finally, there are the difficulties encountered when the directives are being cast into new legislation and must be made to fit within the existing domestic legal system.

\section{$3 \cdot 3$ \\ EU Court of Justice and the European Court on Human Right as Stand-In Constitutional Courts}

The ban on constitutional review of Parliamentary Acts and Treaties (Article 120 Constitution) has had the effect that the protection offered by the fundamental rights catalogue of the Dutch Constitution is limited. So much so that litigants in criminal and administrative proceedings seem to prefer to invoke fundamental rights from international treaties like the European Convention on Human Rights (directly applicable in the Netherlands) or even the Charter of Fundamental Rights of the European Union, over invoking the rights held

15 CJ EC Flaminio Costa v. E.N.E.L, C 6/64, Jur. 1964, $1203 \mathrm{ff.}$

16 HR 2 November 2004, NJ 200580. 
in the domestic catalogue. ${ }^{17}$ This in turn results in little or no elaboration of the Dutch fundamental rights in the case law of Dutch courts. In turn it has caused the Luxembourg EU court (acting under the EU treaties and its charter on Fundamental rights) and the ECHR in Strasbourg (acting under the European Convention on Human Rights) to become quite effective stand-in Constitutional Courts in the Netherlands. The combined effects of the priority of international human rights protection (over the national catalogue) and the ban on constitutional review under the Dutch Constitution do not stop here. There are other side effects as well.

Fundamental rights protect freedom or the enjoyment of freedom in relation to government. The oldest generation of fundamental rights typically try to ward off government action and undue interference in the freedom of citizens. Hence, most of the time, fundamental rights as such do or did not play a role in relations between citizens, $i e$ private parties, under Private Law. It is, for instance, still impossible to invoke a right under the European Convention on Human Rights against a fellow citizen. A current trend in a number of national jurisdictions, as in the Dutch one, is the constitutionalization of private law, which entails the development of room for and effect of fundamental rights in private party relations under Private Law. ${ }^{18}$ Influence or effect of fundamental rights in Private Law is a relatively new phenomenon in legal history, a development spurred by the flux of (treaty-based) human rights and basic rights over the last decades. Still, fundamental rights - to a certain extent - remain a strange phenomenon in Private Law. Some have argued that fundamental rights are exclusively written for the relations between a state (or its government) and its citizens. Others have pointed out that in fact fundamental rights are and always have been engrained in Private Law. In its Roman Law origins, Private law already encompassed the protection of certain aspects of human dignity.$^{19}$ Indeed citizen's rights - many of them closely resembling modern day fundamental rights - were in Roman times protected by Private Law, and only claimable in civil law proceedings. ${ }^{20}$ Whatever the position one cares to

17 See J.H. Gerards, W.J.M. Voermans, H.M.Th.D. ten Napel \& M.L. van Emmerik, Juridische betekenis en reikwijdte van het begrip 'rechtsstaat' in de jurisprudentie en legisprudentie van de Raad van State, Den Haag 2011.

18 See J.M. Smits, Private law and fundamental rights: a Sceptical View, in: T. Barkhuysen and S. Lindenbergh (ed), Constitutionalisation of Private Law, Leiden 2006, 9-22.

19 S. Banakas, The Constutionalization of Private Law in the UK: Is there an Emperor inside the New Clothes, in: Barkhuysen and Lindenbergh, 83 .

20 As is very vividly depicted in T. Holland's novel Rubicon; the Triumph and Tragedy of the Roman Republic, London 2004. Lawyers like Cicero were especially well trained and skilled in extracting citizen's dignities from private law rights and demonstrating that in 
take, this form of constitutionalization is already visible in Dutch case law as well as in case law in other European countries, ${ }^{21}$ and the Dutch government, for instance, already alluded to these effects of fundamental rights in horizontal' relations at the occasion of the constitutional reform of 1983. Still in other ways, fundamental rights permeate into Private Law, for instance, when Private Law (e g liability law) is used as instrument to enforce fundamental rights. ${ }^{22}$

The Dutch system of constitutional review is a strange one indeed and it does not chime well with the systems of its European neighbours. With its constitutional ban on constitutional review and the absence of a Constitutional Court, it is the odd one out in the European family. Still the Dutch seem content with their system. It stems from a long tradition in which the primacy of Parliament was favoured over judicial supremacy under the constitution. A balance that seems to be working for a country dominated by a lot of (rivalling) minorities. There is however more than meets the eye. At closer inspection the Dutch do enjoy full constitutional review for constitutional courts albeit not under their own domestic constitution or constitutional court. Due to their openness for international law and the domestic and direct effect of self-executing treaty provisions the Dutch enjoy constitutional (fundamental rights) protection that is on par with that of its European neighbours. And the Dutch are able to invoke these rights, not necessarily before a national court, when it comes down to issues with Acts of Parliament, but before international ones. This is true to Dutch nature: a land of quarrelsome minorities but always open to the open seas and outer world.

fact these dignities were the foundations of these private rights. This constituted a sort of a 'Lüth-doctrine'- avant-la-lettre (see G. Brüggemeier, Constitutionalization of Private Law - the German Perspective, in: Barkhuysen and Lindenbergh, 69-72. Romans were very susceptible to these notions of citizen's or human dignity as the core of their law and flocked to public show-trials where these issues were at stake in civil law proceedings. They revelled in the public display of legal wit of great lawyer-orators. Much has changed since.

21 See C. Mak, Fundamental Rights in European Contract Law. A comparison of the impact of fundamental rights on contractual relationships in Germany, the Netherlands, Italy and England, thesis University of Amsterdam 2007, Alphen aan den Rijn 2008.

22 See J.M. Emaus, Enforcing ECHR rights by means of liability law; Inserting the concept of a breach of a fundamental right into Dutch civil law, thesis Utrecht University, The Hague 2003 . 